the Institute remains its study programme, and the year was the last full year in which financial help will be received from the Nuffield Foundation for studies of development problems. Five studies have been published dealing with British aid, one with German aid, another with Japanese aid, and a third on the Jeanneney Report dealing with French aid, as well as others dealing with India at 'midpassage', aid to Africa, aid to the West Indies and with assistance rendered "Not by Governments Alone". Other studies during the year have included a special examination of private investment and one of British aid to agriculture. Projected investigations include one of recipients, another of donors, an annual survey of Britain's aid problem and others dealing with trade and with the private sectors. Financed by a special grant from the Nuffield Foundation, the first three of the Institute's Nuffield Fellows went to Uganda, Kenya and Tanganyika in the summer of 1963 , and three more Fellows were sent out in 1964. A further and increased grant from the Nuffield Foundation has made it possible to appoint six Fellows this year for 1965-67 and six next year for 196668. The Governments which will employ the Fellows are asking for twenty new Fellows this year, and applications have been received from about fifty candidates in the United Kingdom.

\section{Analysis and Planning of Management}

IN an article reprinted from Personnel Management, June 1965 , Mr. M. Hull argues that the analysis and planning of manpower have been neglected both at the level of the firm and over the economy as a whole. After describing the technical potential of the computer in this field, he points out that standardized codings of labour are required for educational and occupational purposes. $\mathrm{He}$ suggests that a statistical manpower grid, derived from the records of firms with mechanized payrolls, ideally coding on similar lines, could provide valuable information on the utilization of manpower, including correlations between industrial usefulness and academic qualifications. Such a system, he considers, is both technically and economically possible and would enable the supply of labour at all levels to be related better to needs.

\section{Abbé Lazzaro Spallanzani}

IT is just 200 years since the Abbé Lazzaro Spallanzani (1729-99) anticipated Pasteur's work and that of John Tyndall when he banished the idea of spontaneous regeneration of living matter, a contribution soon forgotten since it was beyond the comprehension of the scientists of his day. Philosophers such as Diderot had directed attention to this question, discussing in his Interpretation of Nature whether living matter could combine with living matter, whether "the energy of a living molecule could vary by itself or according to the dead or living matter with which it united". The two priests Needham and Spallanzani took up the themeafter Needham had studied "very small organisms" with Buffon. Needham visualized a productive or vegetative force charged with the formation of organic matter. Spallanzani examined Needham's method of enclosing putrescible matter in vessels warmed to produce animalculae (as he thought), and the controversy between the two opened. Spallanzani realized that Needham had not used a sufficiently high temperature to destroy bacteria or "seeds" of living matter as he called them. By avoiding porous cork or stoppers on vessels, and using sealed vessels maintained for an hou in boiling water, Spallanzani found on opening them that "not the slightest trace of animalculae remained, though I had examined with a microscope the infusions from 19 different vessels". Despite his accurate observations and the controlled conditions which he used to verify his results, Spallanzzni was little appreciated, and the full significance of his work had to await the work of Pasteur and of Nicolas Appert. Even the vigorous attack on Needham by Voltaire, who was ever ready to cross a nib to deride "the Irish Jesuit" as he called him, did not help recognition of Spallanzani's work. Voltaire jested at a race of so-called eels which had their origin in gravy from boiled mutton; at philosophers who claimed there is no germ, that all is regenerated by a vital force of nature. He derided "clever scientists taken in by a Jesuit", although Needham had been "so triumphantly refuted by M. Spallanzani".

\section{Museum of Comparative Zoology, Harvard University}

THE annual report of the Museum of Comparative Zoology at Harvard University directs attention to the considerable expansion which has taken place during 1963-64 both in teaching and research activities (Pp. 40. Cambridge, Mass.: Museum of Comparative Zoology, Harvard University, 1965). As in previous years, many members of staff were invited to give lectures at congresses, conferences and seminars. Field research included expeditions to East Africa, Anatolia, Turkey, and an Indian Ocean investigation aboard the $\mathrm{R} / \mathrm{V}$ Anton Brum. Research centred around evolutionary biology and such problems as : How did the enormous diversity of life on this world evolve?; What are the mechanisms, the causal determinants and the environmental conditions? Recognizing that it is as true to-day as it was 200 years ago that sound taxonomy is the indispensable basis of all research in zoology and botany, at least part of the time of the staff is devoted to basic taxonomic researches. In this connexion Prof. F. M. Carpenter has nearly completed his insect volume for the Treatise on Invertebrate Paleontology, and Dr. B. W. Evans has completed his revision of the genus Rhabdepyris, probably the most generalized group of the large sub-family Epyrinae.

\section{The University Museum, Oxford}

ON May 1, 1964, the Delegacy for the University Museum, established in 1853, ceased to exist, its place being taken by the Delegacy for the Science Area. Fuller responsibility for the Museum proper is now vested in the Committee for the Scientific Collections. In view of serious overcrowding and the need to provide for the proper display and expansion of the collections, the suggestion in the Holford Report that new accommodation for the Pitt-Rivers Museum should be provided, in association with the Institute of Social Anthropology and the Research Laboratory for Archaeology, was welcomed. For the immediate future, a modern, artificially-lit exhibition gallery, of approximately 600 square feet, has been built immediately inside the Pitt-Rivers Museum court at the foot of the main entrance stairs from the University Museum (Seventy-sixth Report of the Delegates of the University Museum and First Report of the Delegates of the Science Area. (For the year ending July 31, 1964.) Supplement No. 4 to the University Gazette, March 1965. Pp. 133. Oxford: The University. 10s.).

\section{Catalogue of Bronze Implements}

THE card catalogue of British bronze implements, started by the British Association in 1913, has since 1955 been on loan to the Department of European Archaeology at Oxford, where it has been brought up to date under the supervision of Prof. C. F. C. Hawkes. Early in October this year it will be returned to the British Museum and installed in the new Students' Room of the Sub-department of Prehistory and Roman Britain.

\section{Diamonds in Metalworking}

THE use of diamond tooling in machining very hard materials has been known for many years. The problem of sintered tungsten carbide in this connexion was faced during the 1920's and only diamond was found hard enough to solve it satisfactorily. From this inception 